\title{
SOSIALISASI BANTUAN HUKUM BAGI MASYARAKAT MISKIN DALAM RANGKA KESADARAN HUKUM
}

\author{
${ }^{1 *}$ Artaji, ${ }^{2}$ Hazar Kusmayanti, ${ }^{3}$ Ali Abdurachman \\ Universitas Padjadjaran \\ Email : ${ }^{1}$ Artaji@unpad.ac.id
}

Manuskrip: Okt-2020; Ditinjau: Nov -2020; Diterima: Nov-2020; Online: Jan-2021; Diterbitkan: Jan-2021

\begin{abstract}
ABSTRAK
Lembaga bantuan hukum lahir karena adanya suatu harapan baru dalam membantu masyarakat berhadapan dengan hukum yang tidak mampu baik secara ekonomi maupun kedudukan strata sosial serta minimnya pengetahuan hukum mereka, selain itu terdorong karena keinginan dalam mewujudkan supremasi hukum bagi seluruh warga Negara, keberadaannya pun sangat penting ditengahtengah masyarakat mengigat prinsip persamaan di depan hukum. Dalam pengabdian pada masyarakat ini nantinya akan membicarakan seputar kegiatan Sosialisasi Bantuan Hukum Gratis Bagi Masyarakat Miskin merupakan upaya untuk memaksimalkan program bantuan hukum gratis bagi masyarakat miskin sebagai pemenuhan akses keadilan bagi masyarakat kurang mampu. Metode yang dipergunakan dalam kegiatan ini adalah diskusi terarah dengan sasaran masyarakat diskusi ini diikuti oleh semua unsur yang berkepentingan. Berdasarkan hasil penyuluhan didapat hasil terjadinya peningkatan pengetahuan, pemahaman serta kemampuan para masyarakat di Desa Sayang Kecamatan Jatinangor Sumedang mengenai prosedur bantuan hukum gratis untuk masyarakat miskin.
\end{abstract}

\section{Kata Kunci : Lembaga Hukum, Masyarakat Miskin, Jatinangor.}

\section{PENDAHULUAN}

Permasalahan hukum terjadi karena beberapa hal, antara lain diakibatkan oleh lemahnya sistem peradilannya, buruknya mentalitas penegak hukum, intervensi kekuasaan, maupun produk hukum yang i-relevan, kondisi tersebut diperburuk dengan rendahnya kesadaran hukum masyarakat sehingga tidak paham terhadap aturan aturan yang ada, seperti ketika ada undang-undang bantuan hukum tahun 2011 masyarakat tidak semua tau adanya bantuan hukum diberikan kepada orang miskin dalam menjamin keadilan hak nya, namun di sisi lain masyarakat menuntut akan keadilan dihadapan hukum. Pengabdian Kepada masyarakat mengenai Sosialisasi Bantuan Hukum Bagi Penduduk dilakukan di Desa Sayang sangat diperlukan mengingat di daerah ini sangat banyak penduduk yang bertaraf ekonomi di bawah Upah Minimum Regional (Selanjutnya disebut UMR). 
Proses penegakan hukum perdata dewasa ini selain penyelesaiannya membutuhkan waktu cukup lama bahkan dalam biaya perkara pun relatif tinggi sebagaimana ketentuan Pasal 2 Perma No. 3 Tahun 2012. Berdasarkan Perma No. 3 tahun 2012. Lembaga bantuan hukum lahir karena adanya suatu harapan baru dalam membantu masyarakat berhadapan dengan hukum yang tidak mampu baik secara ekonomi maupun kedudukan strata sosial serta minimnya pengetahuan hukum mereka, selain itu terdorong karena keinginan dalam mewujudkan supremasi hukum bagi seluruh warga Negara, keberadaannya pun sangat penting ditengah-tengah masyarakat mengigat prinsip persamaan di depan hukum. Cita bantuan hukum tidak lain adalah supremasi hukum, namun perlu kiranya membedaakan antara bantuan hukum yang diberikan oleh kentor advokat dan lembaga bantuan hukum, karena jelas dalam Undang-undang No. 16 tahun 2011 lembaga bantuan hukum bersifat nonprofit padahal dapat kita jumpai lembaga bantuan hukum yang menyampaikan peran lembaganya salah satunya adalam membuka lapangan kerja, padahal seharusnya orang yang masuk dalam lembaga bantuan hukum tidak lah semata mengejar materi namun lebih pada dedikasi (pengabdian) kepada bangsa dan Negara untuk menjadi bagian dari penegak hukum dalam menjamin hukum yang berkeadilan. Oleh karena itu Tim Penelitian Riset Kompetensi Doktor Unpad, pada kesempatan kali ini akan memberikan Penyuluhan Hukum mengenai Bantuan Hukum Bagi Masyarakat Miskin.

\section{METODE PELAKSANAAN KEGIATAN}

Metode yang dipergunakan dalam kegiatan ini adalah diskusi terarah dengan masyarakat, diskusi ini diikuti oleh semua unsur yang berkepentingan dengan prosedur Bantuan hukum kepada masyarakat miskin ini diatur dalam Pasal 33 UU Nomor 16 Tahun 2011 tentang Bantuan Hukum.

\section{HASIL DAN PEMBAHASAN}

Pada hari Sabtu Tanggal 12 September 2020, tim penelitian RPLK yang diketuai oleh Dr. H. Artaji. S.H., MH. melakukan penyuluhan hukum mengenai pembagian hak mewaris anak angkat menurut hukum adat dan hukum Islam.dalam rangka meningkatkan kesadaran hukum bagi masyarakat Desa Sayang Kecamatan Jatinangor. Kegiatan Penyuluhan ini diadakan di Kantor Desa Sayang Jalan Kolonel Ahmad Syam No.226, Sayang, Jatinangor, Kabupaten Sumedang, Jawa Barat 45363 dengan dihadiri oleh sekitar 40 orang peserta yang terdiri dari aparatur Desa, Perwakilan pengurus Lembaga Swadaya Masyarakat, pihak kepolisian, dan anggota masyarakat. Pemaparan Penyuluhan hukum mengenai Sosialisasi Bantuan Hukum Bagi Masyarakat Miskin Dalam Rangka Kesadaran Hukum, disampaikan oleh salah satu anggota tim penelitian RKDU sekaligus dosen yang pakar dalam ilmu Hukum Acara Perdata yaitu Bapak Dr. H. Artaji, S.H., M.H., sebagai narasumber. 


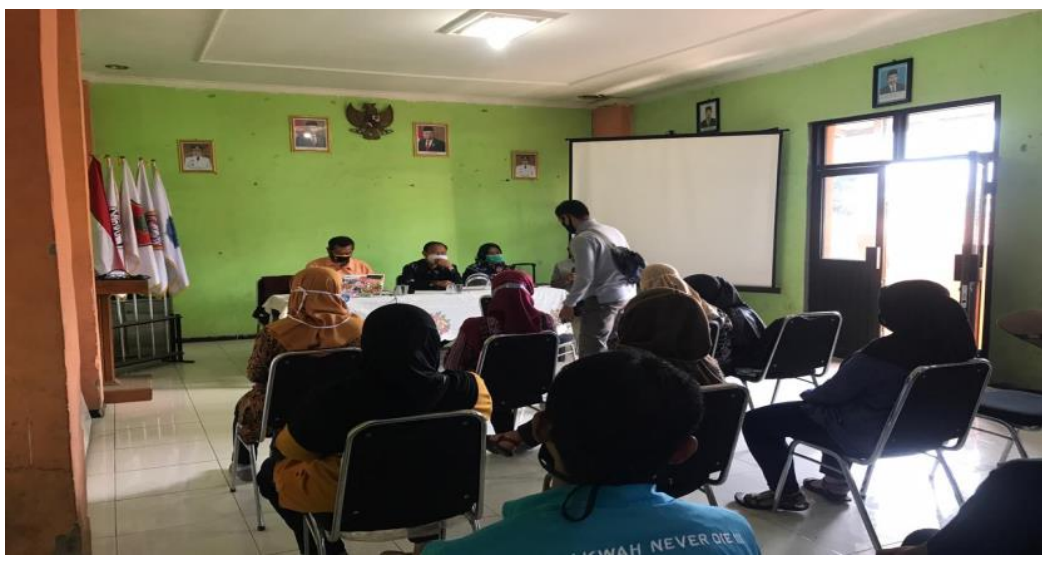

Gambar 1. Pemaparannya dari anggota PKM

Sesi Pertama adalah pemaparannya dari Dr. H. Artaji, S.H., M.H menjelaskan hal-hal terkait hak-hak tenaga kerja, pengertian lembaga Bantuan Hukum dan Hubungan LBH dan Advokat, Perbedaan Advokat dan LBH dan prosedur untuk melakukan Pendampingan Hukum secara Cuma-Cuma. Tim penyuluh berharap dengan diadakannya kegiatan ini dapat menjadi sarana penyebarluasan informasi adanya program bantuan hukum gratis kepada masyarakat miskin sehingga terwujud pemerataan pemberian bantuan hukum gartis kepada masyarakat miskin di Jatinangor serta memacu tingkat kesadaran hukum masyarakat ke jenjang yang lebih baik lagi.

Sesi Kedua adalah Diskusi dilakukan setelah pemaparan penyuluhan dilakukan, antusias dari warga pun sangat terlihat dari beberapa pertanyaan yang diajukan diantaranya adalah sebagai berikut :

1. Bapak Cecep (perwakilan dari tokoh masyarakat) : Bagaimana syarat untuk mendapatkan bantuan Hukum Cuma-cuma!

2. Bapak Lilik (perwakilan dari Ojek online) : Apa saja Tupoksi LBH ?

3. Bapak Agus (Guru sekaligus perwakilan dari Lembaga Pemberdayaan Masyarakat) : Sengketa apa sajakah yang ditangani oleh LBH ?

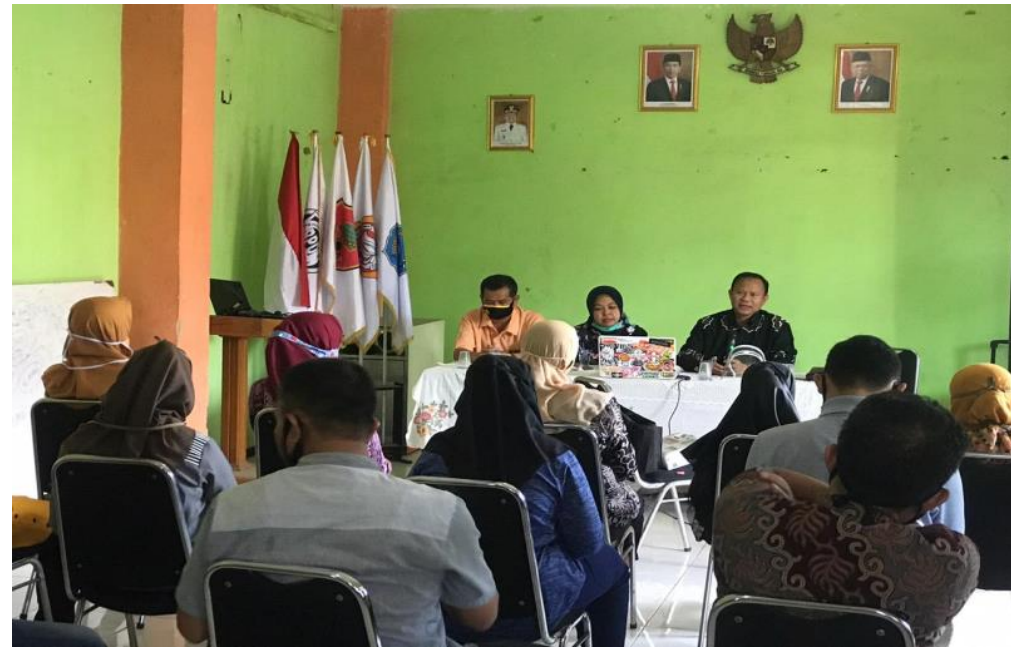

Gambar 2. Pembahasan dari Pertanyaan 
Sesi ketiga adalah Pemahasan pertanyaan :

1. Syarat Penerima Bantuan Hukum Cuma-Cuma

Syarat penerima bantuan hukum cuma-cuma yang disebutkan di dalam peraturan perundang-undangan adalah miskin, di mana definisi miskin sendiri adalah tidak dapat memenuhi hak dasar secara layak dan mandiri. Sehingga setiap kelompok atau orang perorangan yang ingin mengajukan bantuan hukum cuma-cuma harus dapat menunjukan keterangan miskin atau dokumen lain yang menunjukan status miskin tersebut, seperti Kartu Jaminan Kesehatan Masyarakat, Bantuan Langsung Tunai atau Kartu Beras Miskin.

Namun, dalam pelaksanaannya di lapangan, syarat miskin terkadang tidak digunakan atau tidak didefiniskan seperti yang tertuang di dalam peraturan perundang-undangan. Ada beberapa lembaga bantuan hukum atau organisasi kemasyarakatan yang tidak mensyaratkan status miskin atau mendefiniskan miskin tidak hanya secara materi, namun juga secara pengetahuan hukum.

Benar-Benar Gratis. Pemberi bantuan hukum cuma-cuma dilarang untuk menerima atau meminta bayaran kepada penerima bantuan hukum cuma-cuma terkait dengan bantuan hukum yang diberikannya, bahkan hal tersebut diancam dengan hukuman pidana penjara paling lama 1 (satu) tahun atau denda paling banyak Rp 50.000.000,00 (lima puluh juta rupiah). Hal ini diatur di dalam Pasal 20 junto Pasal 21 Undang-Undang Nomor 16 Tahun 2011 tentang Bantuan Hukum.

2. Salah satu kelompok hukum yang tidak bisa dipisahkan dari kehidupan masyarakat adalah hukum perdata yaitu segala aturan hukum yang mengatur hubungan hukum antara orang yang satu dengan orang lain dalam hidup bermasyarakat, hubungan hukum tersebut dapat terjadi karena, perjajian antara pihak satu dengan pihak lain, ketentuan undang-undang yang bermanfaat atau saling menguntungkan bagi pihak-pihak, atau ketentuan undang-undang yang merugikan orang lain misalnya perbuatan melawan hukum, maka dapat disimpukan sebagai akibat berikutnya hukum perdata adalah pelaksanaan dan pemenuhan realisasi kewajiban diantaranya: Pertama apabila kedua belah pihak memenuhi kewajiban dan hak timbal balik secara penuh, Kedua apabila salah satu pihak tidak memenuhi kewajibannya, dan Ketiga apabila kerugian akibat perbuatan melawan hukum (onrechtmatige daad).

3. Dalam Undang-undang No. 16 Tahun 2011 lembaga bantuan hukum bersifat non profit padahal dapat kita jumpai lembaga bantuan hukum yang menyampaikan peran lembaganya salah satunya adalam membuka lapangan kerja, padahal seharusnya orang yang masuk dalam lembaga bantuan hukum tidak lah semata mengejar materi namun lebih pada dedikasi (pengabdian) kepada bangsa dan Negara untuk menjadi bagian dari penegak hukum dalam menjamin hukum yang berkeadilan.

Dalam rangka menjalankan pelayanan yang professional kepada masyarakat di bidang hukum, mulai dari prosedur pemberian konsultasi hukum, pendampingan Hukum, Penyuluhan dan Pendidikan Hukum serta penelitian dan kajian hukum LKBHI menetapkan prosedur sebagai berikut; 
a. Konsultasi Hukum dan Pendampingan Hukum Klien yang datang diterima oleh bagian pendaftaran (front office) untuk di daftar dan mengisi formulir konsultasi yang disediakan. Klien dapat menulis identitas diri dan pokok persoalan hukum yang akan dikonsultasikan. Setelah itu klien diantar ke divisi hukum dan advokasi untuk ditunjukkan konsultan hukumnya sesuai dengan pokok persoalan hukum yang ditulisnya dalam blanko konsultasi.

b. Penyuluhan hukum melakukan kerjasama baik dengan instansi pemerintah ataupun dengan kelompok masyarakat, kemudian melihat kebutuhan pada masing masing pihak yang sudah bekerjasama, kemudian dilakukan penyuluhan hukum dalam bentuk Focus Group Discussion (FGD) dan Seminar hukum oleh Angoota LKBHI sesuai dengan keahliannya pada bidang masing-masing.

c. Penelitian dan Kajian Hukum Out Put dari penyuluhan hukum terhadap masyarakat langsung kemudian dilakukan kajian atas temuan masalah yang baru dan dilakukan penelitian ulang untuk menelaah permasalahan secara ilmiah demi terwujudnya solusi yang bisa menciptakan budaya hukum yang baik

4. Lembaga bantuan hukum lahir karena adanya suatu harapan baru dalam membantu masyarakat berhadapan dengan hukum yang tidak mampu baik secara ekonomi maupun kedudukan strata sosial serta minimnya pengetahuan hukum mereka, selain itu terdorong karena keinginan dalam mewujudkan supremasi hukum bagi seluruh warga Negara, keberadaannya pun sangat penting ditengah-tengah masyarakat mengigat prinsip persamaan di depan hukum Lembaga bantuan hukum lahir karena adanya suatu harapan baru dalam membantu masyarakat berhadapan dengan hukum yang tidak mampu baik secara ekonomi maupun kedudukan strata sosial serta minimnya pengetahuan hukum mereka, selain itu terdorong karena keinginan dalam mewujudkan supremasi hukum bagi seluruh warga Negara, keberadaannya pun sangat penting ditengah-tengah masyarakat mengigat prinsip persamaan di depan hukum.Sebagai lembaga yang bergerak dalam bidang bantuan hukumsalah satu kewajibannya secara umum adalah melakukan penanganan perkara Litigasi dan Non litigasi untuk dengan penuh tanggung jawab dan meberikan pelayanan yang baik secara hukum, adapun perkara litigasi dan non litigasi sebagai berikut :

a. Litigasi : adalah perkara yang masuk dalam ruang pengadilan yaitu :

1) perkara pidana

2) perdata dan

3) Tata Usaha Negara

b. Non Litigasi : adalah perkara di luar persidangan yaitu;

1) Penyuluhan hukum

2) Konsultasi hokum

3) Mediasi

4) Konsiliasi Penelitian hukum

5) Pemberdayaan masyarakat

6) Penanganan perkara diluar pengadilan 
7) Drafting hukum Penelitian hukum

\section{KESIMPULAN DAN SARAN}

Melalui Pengabdian kepada masyarakat ini peningkatan pengetahuan, pemahaman serta kemampuan para masyarakat di Desa Sayang Kecamatan Jatinangor Sumedang terkait sosialisasi Bantuan Hukum Bagi Masyarakat Miskin selama 1 hari ini dapat berjalan lancar. Para peserta kegiatan PKM yang hadir bersemangat dalam mengikuti jalannya sosialisasi dan penyuluhan hukum sebab tema yang disajikan sangat aktual dalam hampir keseluruhan masyarakat Desa Sayang Jatinangor masih belum mengetahui prosedur bantuan hukum bagi masyarakat miskin menjadi sadar hukum dan mengerti bagaimana hukum mewaris khususnya anak angkat. Namun Perlu ditingkat lagi sosialisasi mengenai prosedur bantuan hukum bagi masyarakat miskin kepada masyarakat terutama di daerahdaerah atau di desa-desa lain yang sasaran masyarakatnya sudah memiliku tingkat perekonomian yang rendah, sehingga diharapkan masyarakat sudah memahami tentang tata cara mengetahui prosedur bantuan hukum bagi masyarakat miskin

\section{DAFTAR PUSTAKA}

Abdul Kadir Muhammad, Hukum Perdata Indonesia, Bandung: PT Citra Aditya Abadi, 2014

Bambang Sri, Sutiyoso, Hukum Acara Perdata dan Perkembangannya Di Indonesia, Yogyakarta : Gama Media. 2007.

Hariyanto, Peran LBH Kampus Di PTKIN Dalam Bantuan Hukum Terhadap Masyarakat Miskin, Jurnal Al Adl, Vol. 10 No. 1, Januari 2017

M. Yahya Harahap, Hukum Acara Perdata : gugatan, Persidangan, Penyitaan, Pembuktian, dan Putusan Pengadilan, Jakarta : Sinar Grafika. 2005.

Purwanto, A., Sunarsi, D., \& Wijoyo, H. (2020). Penerapan Perluasan Arti Perbuatan Melanggar Hukum Dalam Pelaksanaan UU 29 Tahun 2004 (Studi Kasus Putusan No. 625/PDT. G/2014/PN JKT. BRT). TIN: Terapan Informatika Nusantara, 1(2), 99-103.

Rahmadi Usman, Pilihan Penyelesaian Sengketa di Luar Pengadilan, 2019.

Sudikno Mertokusumo, Hukum Acara Perdata Indonesia, Yogyakarta : Liberty. Wardah, 2009.

T.Mulya Lubis, Bantuan Hukum dan Kemiskinan Struktural, Jakarta: LP3ES, 1986 